\title{
A Simultaneous Observation System of the Electric Potentiai Gradient and the Precipitation Charge in the Lower Atmospheric Layer
}

\author{
By Yoshio Asuma, Katsuhiro Kikuchi, Takashi Taniguchi \\ Department of Geophysics, Faculty of Science, \\ Hokkaido University, Sapporo 060, Japan \\ and \\ Satoshi Fujii \\ Radio Research Laboratories, Ministry of Posts and \\ Telecommunications, Tokyo 184, Japan \\ (Manuscript received 2 July 1987, in revised form 25 September 1987)
}

\begin{abstract}
To investigate the mirror image relation between the electric potential gradient and charges on precipitation particles above the ground surface, a simultaneous observation system of the vertical structure of the electric potential gradient in the lower atmospheric layer and the charge on precipitation particles falling through the layer during a snowfall was developed. This system consists of a tethered balloon, observation stages on the tether and a microcomputer on the ground. Each stage has a field mill and a charge collector and it is possible to measure simultaneously the vertical component of the atmospheric electrical potential gradient and the maximum charge on precipitation particles of at most 4 stages at 5 -second intervals at every 50 or $100 \mathrm{~m}$ in altitude. Data are converted to digital signals at the stage, transmitted by digital optical communications with optical plastic fiber cables and stored in microcomputer on the ground.

Several measurements were carried out in March 1985 and some results were obtained. The mirror image relation was observed on the ground but it was not so clear aloft. It was considered that the charges on the precipitation particles were reelectrified during their falling near the ground surface.
\end{abstract}

\section{Introduction}

The electric potential gradient and charge on precipitation particles have been observed since a beginning of this century in order to study the electric activity of thunderstorms. The results of these observations are summarized in publications, for instance, Chalmers (1967), Magono (1980) and so on. It is well known that the mirror image relation is often observed between polarities of the electric potential gradient and of charges on precipitation particles on the ground. That is to say, their polarities are opposite signs with each other. From careful observations of the atmospheric electrical elements up to the present, this relation is almost always observed in the case of snowfall, on the other hand it is not so clear in the case of rainfall (Kikuchi et al., 1979; Tsuboya, 1980).

To investigate this relation in detail, we carried out numerical experiments on the vertical structures of electrical elements below the cloud 
base during snowfall and rainfall (Asuma and Kikuchi, 1987). In these numerical experiments, modifications of the charge on precipitation particles below the cloud base were examined. They were reported that the vertical structures of the spatial distribution of the charge on snowflakes largely changes near the ground and the mirror image relation observed on the ground is affected by the phenomenon near ground surface. To verify these results, we designed a simultaneous observation system of the vertical structures of the electric potential gradient and precipitation charge on individual snowflake at the several different heights above the ground surface using a tethered balloon system. In this paper, we will describe this system in detail and will show some results.

\section{Instruments}

Observations on the electrical structures using a tethered balloon system have been reported by Rust and Moore (1974), Standler and Winn (1979), Shigeno and Magono (1983) and so on. These observations were carried out at a single point beneath a balloon during the ascent and/or descent of the balloon. To investigate the fine structures of electric properties, the simultaneity of data is required. One of the effective method to establish our aims is to develop a simultaneous observation system that can simultaneously measured certain atmospheric electrical elements in the lower atmospheric layer at short time intervals. Thus, we designed a simultaneous observation system that has 4 stages in maximum in the lower atmospheric layer and with this system it was possible to measure the electric potential gradient and the amount of the maximum charge on snow particles at 5 -second intervals at heights of $50 \mathrm{~m}$ or $100 \mathrm{~m}$.

\subsection{Constitution of system}

The whole system is illustrated in Fig. 1. This system mainly consists of a tethered balloon, observation stages on the tether and a microcomputer on the ground. A tethered balloon of $35 \mathrm{~m}^{3}$ in volume was used. As the tether, a braided insulated nylon rope $4 \mathrm{~mm}$ in diameter and $500 \mathrm{~m}$ in length was used. Four observation stages were set at every height of $50 \mathrm{~m}$ or $100 \mathrm{~m}$. To remove the effect of the

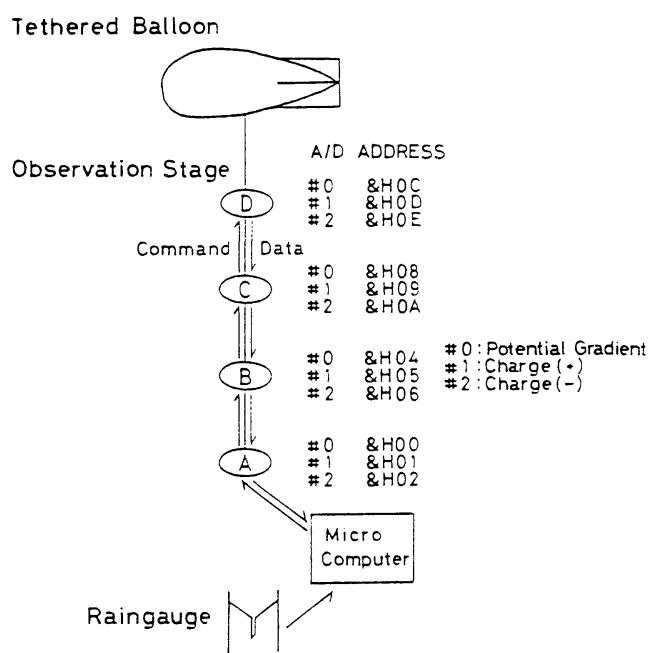

Fig. 1. Outline of the simultaneous observation system.

static charges of the balloon and of snow particles falling from the balloon surface, the uppermost stage was fixed onto the tether $100 \mathrm{~m}$ below the balloon. Each stage was linked with dual optical plastic fiber cables (MRC EH4002) for a digital communication. Application of optical plastic fiber cables has the following advantages; (1) They are good insulators and they do not disturb the electric environment of the atmosphere. (2) It is easier to construct a simultaneous multi-stage communication network than using a wireless system. (3) It is much lighter $(4 \mathrm{~g} / \mathrm{m})$ than the usual dual copper cables.

Three analog to digital (A/D) converters were set on each stage and allocated to three measurement elements. i.e., the electric potential gradient and the positive and negative maximum charge, respectively. As illustrated in Fig. 1, these A/D converters have their own different addresses and they were controlled by the microcomputer on the ground. According to commands which were transmitted from the microcomputer, one of these $\mathrm{A} / \mathrm{D}$ converters is selected and the selected data are transmitted to the microcomputer. And then, they are stored in the microcomputer. Further, a raingauge, which is used for measuring snowfall intensity, is combined with this system.

\subsection{Observation stage}

An observation stage on the tether consisted 
of three parts, that is to say, a field mill, a charge collector and a communication component. The electric potential gradient and the maximum positive and negative charges on snowflakes were measured at 5 -second intervals at each stage. The electric potential gradient was measured by a field mill and the charges were measured by a charge collector. These sensors for the balloon observation were developed first by Magono et al. (1984) and they were improved on their electric circuits and features to fit our observations.

Figure 2 shows an illustration of the apparatus and the electric circuit of the charge collector. Charged snow particles fall through two-fold intake arranged vertically to the receiving vessel and the charge on snow particle which are

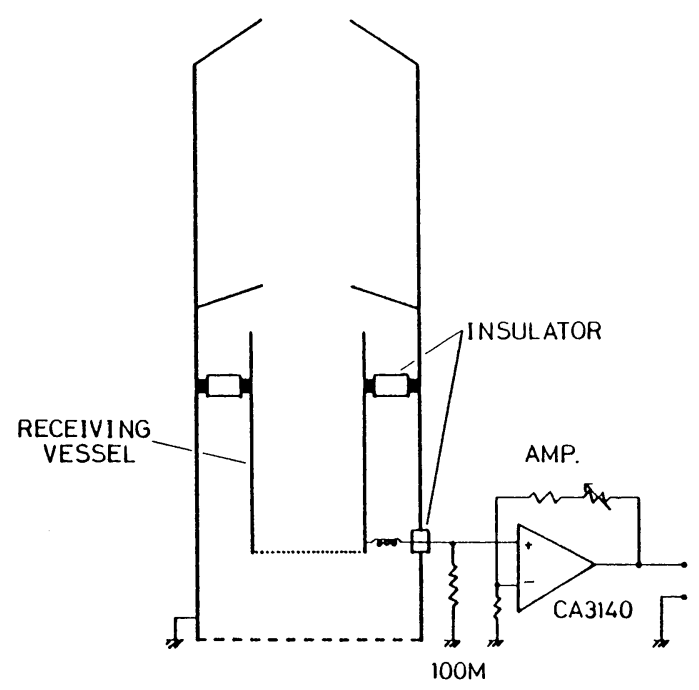

Fig. 2. Illustration of the apparatus and the electric circuit of the charge collector. arrived at receiving vessel is amplified. If a snow particle touches the wall of the upper intake, it is rejected by the lower intake and it does not reach the receiving vessel. The charge on a snow particle flows through the high shunt resistance $(100 \mathrm{M} \Omega)$ and it is amplified by the Bi-MOS operational amplifier IC (RCA CA3140) which has a very high input impedance $(1.5 \mathrm{~T} \Omega)$. The output terminal is connected to the input terminal of the peak hold circuits as shown in Fig. 4.

An electric circuit of the field mill is shown in Fig. 3. A cylindrical can is used as a body of this equipment and at its top and bottom ends there are a pair of quadrant windows. An earthed quadrant rotating metallic shutter and an inductive sensor plate are set below the window. Charges are induced by the atmospheric potential gradient on the inductive plate and they are amplified. To eliminate the effect of charges on the instrument, the difference of the charges induced at the top and the bottom sensor plates is amplified with high impedance differential input amplifier consisting of twin Bi-MOS operational amplifier IC (RCA CA3240). Output signals of this amplifier have an $\mathrm{AC}$ component. To convert these signals to $\mathrm{DC}$, they are mixed with synchronous signals of a rotating shutter with the FET analog multiplexer and then they are rectified. The synchronous signals are detected by a photo interrupter. The output terminal of this field mill is connected to the input terminal of the $A / D$ converter as shown in Fig. 4.

The block diagram of an observation stage on the tether is shown in Fig. 4. Analog to digital conversion is carried out at the obser-

Field Mill

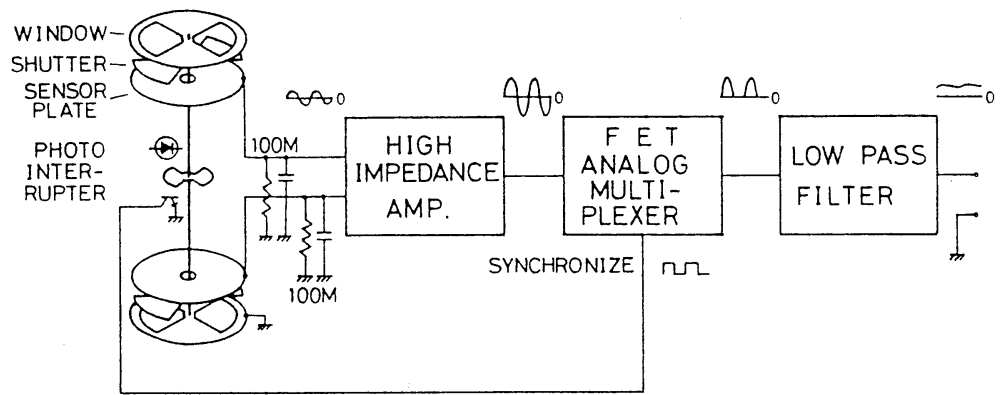

Fig. 3. Electric circuit of the field mill. 
vation stage and data are transmitted by means of digital optical communication. Each stage carries three A/D converters which they are assigned to the electric potential gradient, the peaks of the positive and negative charges on precipitation particles at 5-second intervals, respectively. As mentioned previously the field mill is connected directly to an $A / D$ converter and the charge collector is connected to two $A / D$ converters through the peak hold circuit. We adopt an A/D converter which is a 12 bit binary dual slope integrating $\mathrm{A} / \mathrm{D}$ converter (INTERSIL ICL7109). Each A/D converter has its own different address and it is selected by the address command transmitted from the microcomputer on the ground. Thus, it transmits converted data to the ground. The reset signal of peak hold circuit is also transmitted from the computer on the ground. The communication circuit is shown in Fig. 5. Figure 6 shows the detailed communication circuit in Fig. 5. As described previously, the command and data communication are conducted by optical digital communication signals. The conversion of signals between optical and electrical signals is done in this part with an optical module IC (TOSHIBA TORX-70) for the receiver and with a high bright intensity LED to transmit a longer distance $(50 \mathrm{~m})$ for a transmitter. Commands transmitted from the microcomputer on the ground or the lower stage are received by the optical receiver IC and then are communicated to the received data terminal

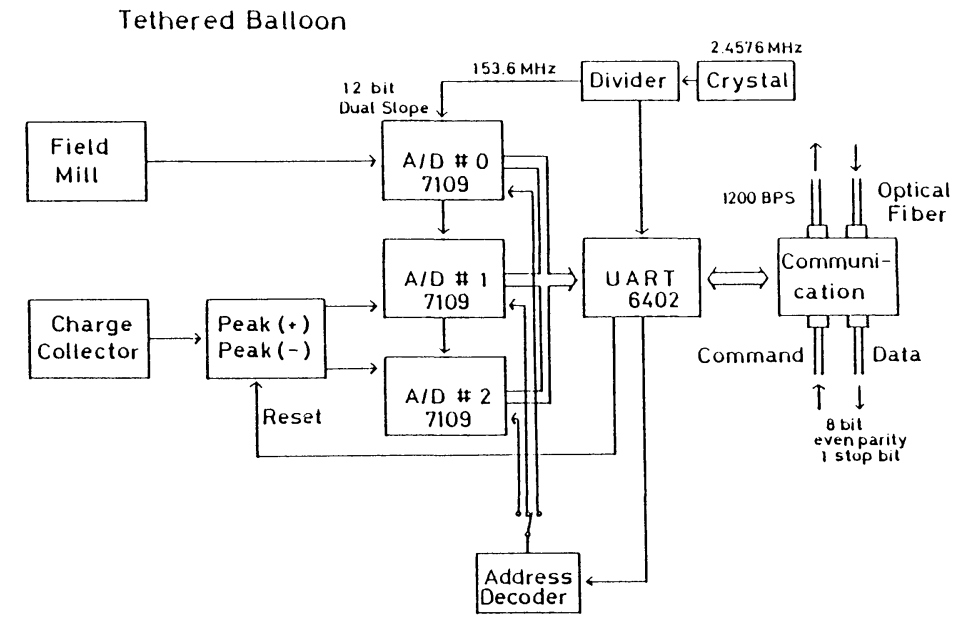

Fig. 4. Block diagram of electric circuit of the observation stage.

Communication Circuit
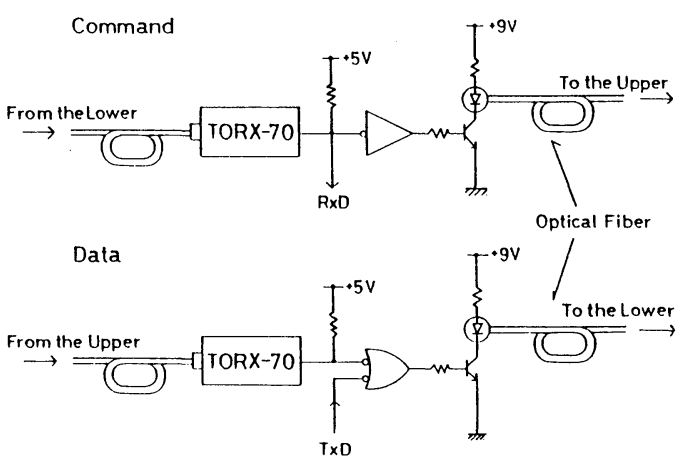

Fig. 5. Communication circuit of the observation stage.
$1 / 0$

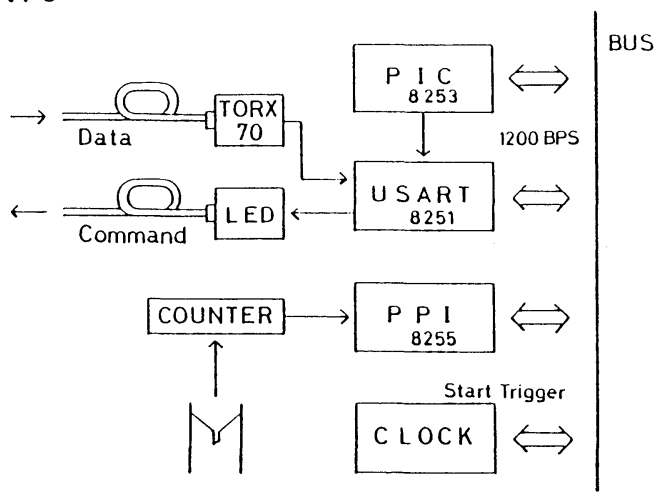

Fig. 6. I/O part of the microcomputer on the ground. 
(RxD) of UART IC and also transmitted the same commands to the upper stage. The selection of address is judged by the address decoder IC. When the $A / D$ converter is selected by an address command transmitted from the microcomputer, it commences to convert to digital signals from its analog data attributed measurement element and converted digital data are transmitted to the lower stage. And also, the same as in the case of commands, data transmitted from the upper stage passes through the lower stage. Thus, from this point of view, this part as shown in Fig. 5 has two operations; one is a transmitting part of its own stage data and another is as a relay for commands and data. Each observation stage is $45 \mathrm{~cm}(\mathrm{H}) \times 50 \mathrm{~cm}(\mathrm{~W}) \times 12 \mathrm{~cm}(\mathrm{D})$ in size and about $2.4 \mathrm{Kg}$ in weight including dry cell batteries.

\subsection{Ground controller}

The controller of this system is basically composed of an 8 bit microcomputer with Z80 CPU (KOJINSHA Micro Decision) and the $\mathrm{I} / \mathrm{O}$ part on the ground. The $\mathrm{I} / \mathrm{O}$ part is shown in Fig. 6. Data and command communication between a microcomputer and each stage on the tether are communicated through the serial I/O IC (USART). The snowfall intensity is also monitored with a raingauge. The rainguage has a heater to melt the received snow particles. The receiving funnel of raingauge is devised that drops of melted water drip with the same mass and the number of drops are counted by a photo interrupter. The time clock IC is mounted on this microcomputer to obtain time records. An observation is carried out under control of the clock signals. Figure 7 shows the entire system of composition of the microcomputer. These systems are operated by a $\mathrm{CP} / \mathrm{M}$ operating system. The part described as $\mathrm{I} / \mathrm{O}$ in Fig. 7 is an observation part on the tether mentioned above. The characteristics of this system are that it has a $512 \mathrm{~K}$ byte RAM disk. As this observation system records data at 5 -second intervals, this interval time is too short to directly write these data into the magnetic floppy disk. To remove this defect, data are once stored in RAM disk and after the end of a series of observations they are restored to the floppy disk for permanent storage. The observed data can be transmitted to other computers with an acoustic coupler or cables through serial I/O (SIO) interface.

Figure 8 shows a flow chart of this observation system. At first, each IC (8253, 8251,

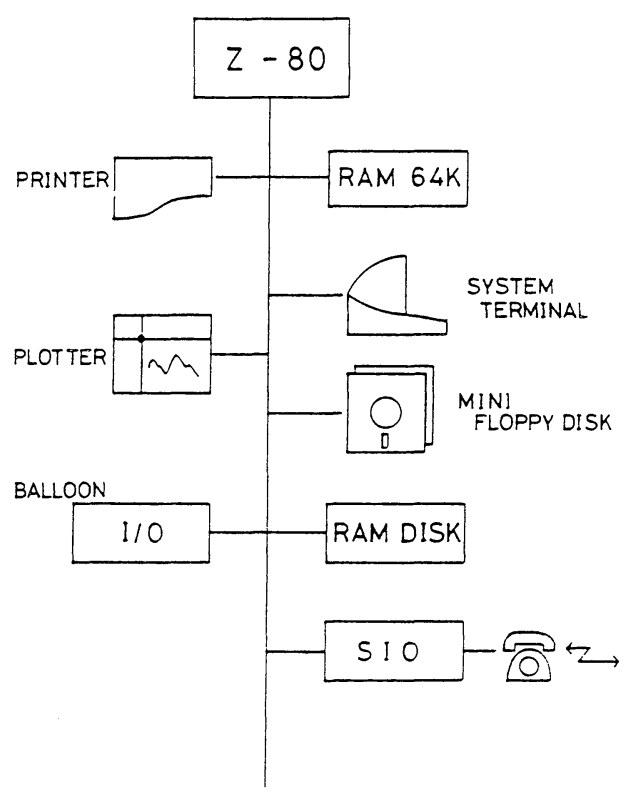

Fig. 7. Arrangement of the microcomputer.

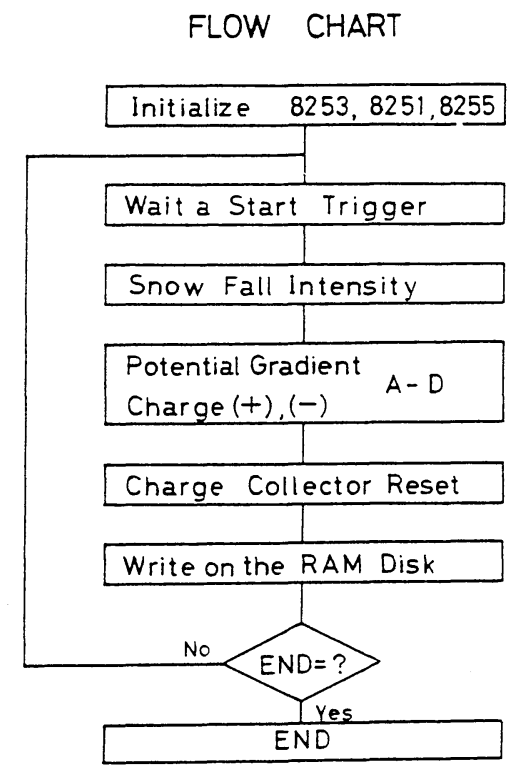

Fig. 8. Flow chart of the observation. 
$8255)$ is set, after that the system is compelled to wait until the trigger signal is sent at each 5second intervals, measure the snowfall intensity with the raingauge, measure the electric potential gradient and the charges (repeat each stage $\mathrm{A}$ to $\mathrm{D}$ as shown in Fig. 1), send a reset signal of the peak hold circuit of charge collector, write data into the RAM disk (one cycle of observations is finished) and wait for the trigger signal for the next observation. After a series of observations were completed, the stored data in the RAM disk are transferred to the floppy disk as described previously.

\section{Results}

It is very difficult to carry out the tethered balloon observations during a snowfall because of strong winds. Thus, several observations were carried out at the side of the building of our laboratory during March in 1985. Unfortunately, however, in those observations the field mill at the ground stage on the tether did not work well. Thus, the data of the electric potential gradient on the ground surface were replaced by the data of another field mill on the flat roof of our building ( $22 \mathrm{~m}$ in height). The values obtained at the roof were several times higher than those on the ground surface. In addition to the data obtained by this system, ion concentrations were also measured by a Gerdien tube (the critical mobility is $0.5 \times 10^{-4} \mathrm{~m}^{2} / \mathrm{Vs}$ ) on the same roof.

Figure 9 shows one of the records obtained by this system. Upper two graphs in Fig. 9 show data at $100 \mathrm{~m}$ and $0 \mathrm{~m}$ (on the ground). The solid lines and the vertical spikes on the abscissa show the electric potential gradient and the charge, respectively. The ion concentration and snowfall intensity are shown in the bottom of two graphs of the figure. As shown in the figure, a wave pattern in the variation of the electric potential gradient was recognized. The wave pattern indicates that the polarity of the electric potential gradient alternately changes throughout the recording period. The flat lines as seen in the records of the electric potential gradient indicate the off scale of the values. The mirror image relation between the polarities of the electric

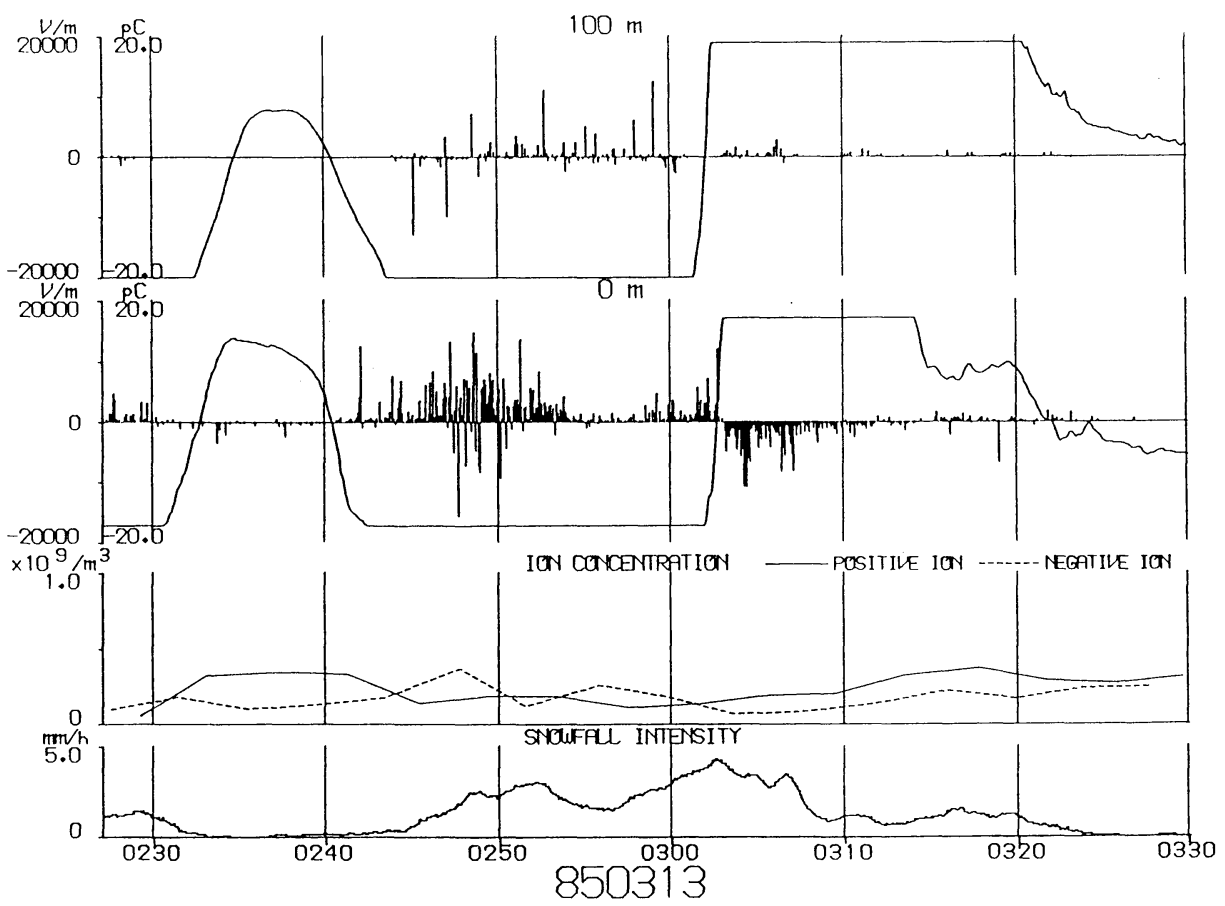

Fig. 9. One of the examples of records obtained at $100 \mathrm{~m}$ above and on the ground by this system on March 13, 1985. 
potential gradient and charge on snow particles holds better on the ground as compared with that at $100 \mathrm{~m}$ height. Thus, the positive charges on snowflakes appear in the case of the negative electric potential gradient and the negative charges appear during the positive electric potential gradient. At $100 \mathrm{~m}$ in height, however, although the variation of the electric potential gradient is similar to that on the ground, the mirror image relation was not always observed.

Figure 10 shows the results at several altitudes, $200 \mathrm{~m}, 100 \mathrm{~m}$ above the ground and on the ground. In this case, the polarity of the electric potential gradient indicated positive at all altitudes. However, the polarity of the charge showed different pattern depending on the altitudes. That is to say, the charges on snow particles were mostly strongly positive at $200 \mathrm{~m}$ above ground, weakly positive and strongly negative at $100 \mathrm{~m}$ above ground and strongly negative on the ground, respectively. Therefore, the mirror image relation was observed only immediately above the ground. According to the naked eye observation on the ground, it

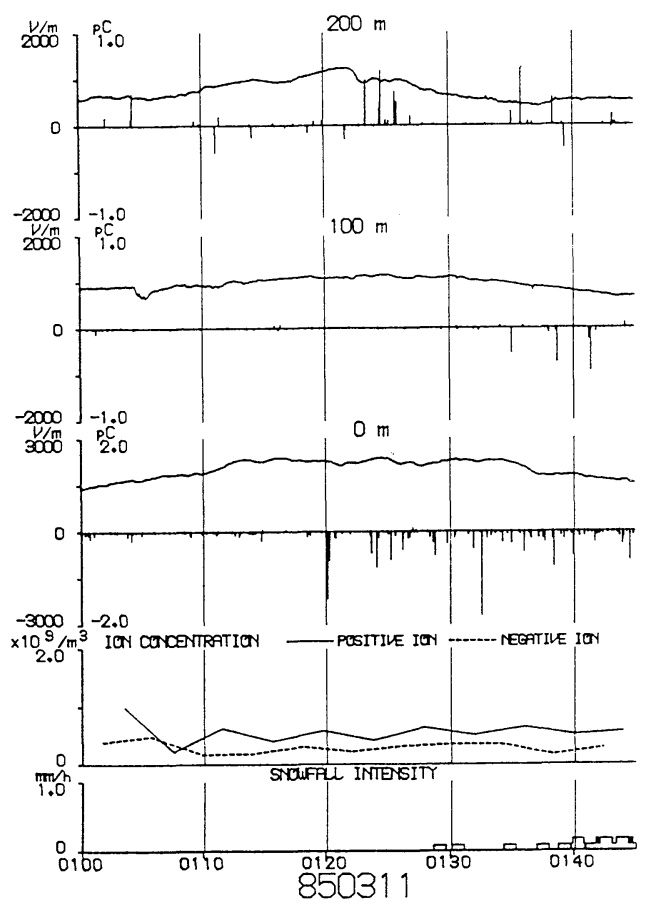

Fig. 10. As in Fig. 9 but for $200 \mathrm{~m}, 100 \mathrm{~m}$ and $0 \mathrm{~m}$ on March 11, 1985. was recognized that the stage at $200 \mathrm{~m}$ above ground was near the cloud base. It is considered therefore that snow particles were charged positively in the cloud and they obtained negative charges during their descent and most of them were charged negatively near the ground surface.

From examples of records shown in Figs. 9 and 10 , it is found that this observation system is useful to investigate the mirror image relation.

\section{Concluding remarks}

A new observation system for the measurement of the vertical structures of the electric potential gradient and charges on the individual precipitation particle during a snowfall above ground was developed. This system consisted of a tethered balloon, observation stages fixed on the tether and a microcomputer stationed on the ground. The stages and the microcomputer were linked with plastic optical fiber cables and the communication was carried out by digital signals. Using this system, the simultaneous observations of the electric potential gradient and charges on snow particles in the lower atmospheric layer could be measured at several different heights at $50 \mathrm{~m}$ or $100 \mathrm{~m}$ apart from each other at 5 -second intervals. We adopted the field mill as a sensor to measure the electric potential gradient and the charge collector to record the charges on precipitation particles. The communication of gathering data and transmitting commands were carried out by means of digital signals. Each stage on the tether had three A/D converters, 12 bit binary dual slope integrating $A / D$ converters, and an analog to digital conversion of data was conducted there. Measurements were carried out obeying commands transmitted from the microcomputer on the ground. And observed data were also stored in it.

Several measurements were carried out in March 1985. The results showed that a mirror image relation was almost always observed on the ground surface but it was not so clear aloft. It was considered therefore that the snow particles were reelectrified during their falling near the ground surface. Further analyses will be reported in Asuma et al. (1987). 


\section{Acknowledgements}

The authors wish to express their gratitude to Mr. H. Sakamoto, Tomakomai Higashi High School and Dr. T. Moriya, the Department of Geophysics, Hokkaido University for their help in design in this system.

A part of this research was supported by a Grant-in-Aid for encouragement of Young Scientists No. 61790129 (Y.A.), the Ministry of Education, Science and Culture of Japan.

\section{References}

Asuma, Y. and K. Kikuchi, 1987: Numerical experiments of the charging mechanism of precipitation particles by the ion-capture process below the cloud. J. Meteor. Soc., Japan. 65, 969-985.

Asuma, Y., K. Kikuchi, T. Taniguchi and S. Fujii, 1987: Vertical structures of the atmospheric electrical potential gradient and the behavior of the precipitation charges during snowfall near the ground surface. J. Meteor. Soc., Japan. (to be published)

Chalmers, J.A., 1967: Atmospheric Electricity. Prega- mon Press. 515pp.

Kikuchi, K., H. Uyeda, T. Takahashi and K. Inatsu, 1979: Atmospheric electrical observations of precipitation particles in the winter monsoon at the Hokuriku district, Japan. J. Fac. Sci., Hokkaido Univ., Ser. 7 (Geophys.), 6, 31-48.

Magono, C., 1980: Thunderstorms. Elsevier Scientific Publishing Company. 261pp.

Magono, C., H. Sakamoto, T. Endoh and T. Taniguchi, 1984: The electrical structure of snow clouds, Part II, Vertical distribution of precipitation charge. J. Meteor. Soc. Japan, 62, 323-334.

Rust, W.D. and C.B. Moore, 1974 : Electrical conditions near the base of thunderclouds over New Mexico. Quart. J. Roy. Meteor. Soc., 100, 450-468.

Standler, R.B. and W.P. Winn, 1979: Effects of coronae on electric fields beneath thunderstorms. Quart, J. Roy. Meteor. Soc., 105, 285-302.

Shigeno, T. and C. Magono, 1983: An observation of the inverse relation between the polarities of electric field and precipitation charge near the ground, as revealed by a tethered balloon.J.Meteor. Soc. Japan, 61, 464-468.

Tsuboya, S., 1980: On the precipitation particle behavior in atmospheric electricity. MS. thesis of Hokkaido Univ. 58pp. (in Japanese)

\section{下層大気中の大気電位傾度と降水電荷の同時観測システム}

\author{
遊馬 芳 雄・菊 地勝 弘・谷口恭 \\ (北海道大学理学部地球物理学教室)
}

藤 井 智 史

(郵政省電波研究所)

地上で観測される大気電位傾度と降水電荷の鏡像関係を調べるために，降雪時の下層大気中の電位傾 度と降水電荷の鉛直構造を同時に測定する钼測システムを開発した。このシステムは係留気球，係留索 上の観測点，地上のマイクロコンピュータから構成されている。観測点にはそれぞれ，フィールド・ミ ルと電荷計を備え， $50 \mathrm{~m}$ あるいは $100 \mathrm{~m}$ 毎に最大 4 点での大気電位傾度の鉛直成分と 5 秒間毎の最大降 水電荷量を同時に測定することがでさる。データは観測点でデジタル変換され，プラスチック光ファイ バー・ケーブルでデジタル光通信され，地上のマイクロコンピュータに保存される。

1985年 3 月に観測を行い，数例の観測結果を得ることができた。鏡像関係は地上では明瞭であるが， 上空では不明膫であること, 降水電荷が落下中地表付近で再带電する様子が観測され，この方法が大気 電気現象の観測に有効であることが示唆された。 